\title{
Manganese Balance Studies in Infants after Operations on the Heart
}

\author{
B. SAMPSON, ${ }^{(22)}$ G. B. BARLOW, AND A. W. WILKINSON \\ Department of Paediatric Surgery, Institute of Child Health, 30 Guilford Street, London WC1N 1EH, England
}

\begin{tabular}{|c|c|c|c|c|c|c|c|}
\hline $\begin{array}{l}\text { Manganese } \\
\text { aged } 3 \text { days } t \\
\text { correction of } \\
\text { flameless ator }\end{array}$ & $\begin{array}{l}\text { alance studi } \\
\text { months, in } \\
\text { ngenital hea } \\
\text { absorption }\end{array}$ & $\begin{array}{l}\text { ummary } \\
\text { have bee } \\
\text { he period } f \\
t \text { defects. } \\
\text { pectroscol }\end{array}$ & $\begin{array}{l}\text { erformed on } \\
\text { lowing opera } \\
\text { mples were } \\
\text { or by solven }\end{array}$ & $\begin{array}{ll}\text { with } \\
\text { tross } \\
\text { 16 infants, } & \text { bloo } \\
\text { tion for the } & \pm 77 \\
\text { analyzed by } & 35 \mathrm{n} \\
\text { t extraction } & \text { tent }\end{array}$ & $\begin{array}{l}\text { 8-hydroxyquinoline follo } \\
\text { opy. A higher mangane } \\
\text { I (710 } \pm 320 \text { nmole } \bullet \text { litr } \\
0 \text { nmole } \cdot \text { litre } \\
\left.\text { nole } \cdot \text { litre }{ }^{-1}\right) \text { compa } \\
\text { of the milks used in oral }\end{array}$ & $\begin{array}{l}\text { wed by flame atc } \\
\text { se content was } f \\
e^{-1} \text { ) or purified } \\
\text { ared with fresh } f \\
\text { travenous drips. } \\
\text { l feeding was } 20\end{array}$ & $\begin{array}{l}\text { nic absorption spec } \\
\text { und in either whol } \\
\text { lasma protein }(113 \\
\text { ozen plasma ( } 215 \\
\text { he manganese con } \\
-300 \text { nmole } \cdot \text { litre }^{-1}\end{array}$ \\
\hline & & & Table & e 1. Clinical feature & of patients & & \\
\hline Patient No. & $\mathrm{Age}^{3}$ (days) & $\begin{array}{c}\text { Length of } \\
\text { balance } \\
\text { (days) }\end{array}$ & Weight (kg) & Diagnosis & Blood/plasma intake & Milk intake & \\
\hline 1 & 23 & 10 & 3.3 & Pulmonary stenosis & $\begin{array}{l}\text { blood day } 1 \text {; } \\
\text { plasma days } 2 \text { and } 3\end{array}$ & $\begin{array}{l}\text { (from day 2) } \\
\text { SMA }\end{array}$ & died age 6 months \\
\hline 2 & 3 & 9 & 4.2 & TAPVD $^{4}$ & plasma day 1 & $\begin{array}{l}\text { (from day } 3 \text { ) } \\
\text { SMA }\end{array}$ & $\begin{array}{l}\text { died } 1 \text { month } \\
\text { after admission }\end{array}$ \\
\hline 3 & 2 & 10 & 3.3 & TAPVD $^{4}$ & plasma to day 4 & $\begin{array}{l}\text { (from day 2) } \\
\text { SMA and } \\
\text { S26 }\end{array}$ & \\
\hline 4 & 43 & 10 & 3.3 & TAPVD $^{4}$ & plasma day 1 & $\begin{array}{l}\text { (from day 2) } \\
\quad \text { S26 }\end{array}$ & \\
\hline 5 & 36 & 10 & 3.8 & $\begin{array}{l}\text { Congenital aortic } \\
\text { stenosis; mitral } \\
\text { regurgitation }\end{array}$ & $\begin{array}{l}\text { blood day } 1 ; \\
\text { plasma to day } 4\end{array}$ & $\begin{array}{l}\text { (from day 2) } \\
\text { SMA }\end{array}$ & \\
\hline 6 & 116 & 11 & 4.6 & $\mathrm{TGA}^{5,}$ & $\begin{array}{l}\text { blood and plasma } \\
\text { day } 1\end{array}$ & $\begin{array}{l}\text { (from day 2) } \\
\text { S26 }\end{array}$ & \\
\hline 7 & 73 & 11 & 4.4 & TAPVD $^{4}$ & $\begin{array}{l}\text { blood day } 1 ; \\
\quad \text { plasma day } 1 \text { and } 2\end{array}$ & $\begin{array}{l}\text { (from day 2) } \\
\text { S26 }\end{array}$ & \\
\hline 8 & 218 & 10 & 6.7 & $\mathrm{TGA}^{5}$ & plasma day 1 & $\mathrm{~S} 26$ & died 1 year later \\
\hline 9 & 153 & 8 & 5.6 & $\mathrm{TGA}^{5}$ & plasma to day 3 & $\begin{array}{l}(\text { from day } 2)^{1} \\
\text { SMA \% S26 }\end{array}$ & \\
\hline 10 & 16 & 11 & 3.5 & TAPVD $^{4}$ & plasma day 1 & $\begin{array}{l}\text { (from day } 2 \text { ) } \\
\quad \text { S26 }\end{array}$ & \\
\hline 11 & 248 & 10 & 5.9 & $\mathrm{TGA}^{5}$ & plasma day 1 & $\begin{array}{l}{\text { (from day } 1)^{1}}^{1} \text { S26 and } \\
\text { SMA }\end{array}$ & \\
\hline 12 & 1 & 10 & 3.0 & TAPVD $^{4}$ & $\begin{array}{l}\text { throughout period } \\
\text { studied }\end{array}$ & $\begin{array}{l}\text { (from day 2) } \\
\quad \text { S26 }\end{array}$ & $(\operatorname{died} 6 / 52)$ \\
\hline 13 & 238 & 10 & 6.9 & $\mathrm{TGA}^{5}$ & plasma days 1 and $2^{2}$ & $\begin{array}{l}(\text { from day } 2)^{1} \\
\text { SMA and } \\
\text { S26 }\end{array}$ & \\
\hline 14 & 97 & 9 & 4.4 & $\mathrm{VSD}^{6}$, heart failure & plasma day 1 & $\begin{array}{l}\text { (from day 2) } \\
\quad \text { S26 }\end{array}$ & \\
\hline 15 & 13 & 9 & 4.5 & TAPVD $^{4}$ & $\begin{array}{l}\text { blood day } 1 ; \\
\text { plasma to day } 3\end{array}$ & $\begin{array}{l}\text { (from day 2) } \\
\text { S26 and } \\
\text { SMA }\end{array}$ & $\begin{array}{l}\text { (died } 21 \text { months } \\
\text { after surgery) }\end{array}$ \\
\hline 16 & 84 & 10 & 3.5 & $\mathrm{TGA}^{5}$ & blood day 1 & $\begin{array}{l}\text { (from day 2) } \\
\text { S26 and } \\
\text { SMA }\end{array}$ & \\
\hline
\end{tabular}

\footnotetext{
${ }^{1}$ Received solid food in addition.

${ }^{2}$ Records of blood and plasma intake incomplete.

${ }^{3}$ At start of balance.

${ }^{4}$ TAPVD, total anomalous pulmonary venous drainage.

${ }^{5} \mathrm{TGA}$, transposition of the great arteries.

${ }^{6}$ VSD, ventricular septal defect.
}

with 8-hydroxyquinoline followed by flame atomic absorption spectroscopy. A higher manganese content was found in either whole blood (710 \pm 320 nmole $\cdot$ litre $\left.^{-1}\right)$ or purified plasma protein (1130 \pm 770 nmole $\cdot$ litre $\left.^{-1}\right)$ compared with fresh frozen plasma (215 \pm 35 nmole $\cdot$ litre $^{-1}$ ) used in intravenous drips. The manganese content of the milks used in oral feeding was $200-300$ nmole $l_{\text {litre }}^{-1}$. 
Total manganese intake was under 200 nmole $\cdot \mathrm{kg}^{-1} \cdot 24 \mathrm{~h}^{-1}$ in infants on milk feeding, but infants receiving solid foods received up to $1500 \mathrm{nmole} \cdot \mathrm{kg}^{-1} \cdot 24 \mathrm{~h}^{-1}$. There was a significant correlation between net intake and net balance $(P<0.01)$ and between intake and faecal loss $(P<0.001)$. Urinary manganese loss is not significant.

Manganese is an essential trace element for both animals and man (15) as a constituent of a number of vital biochemical pathways. Despite numerous observations of deficiency in animals, manganese deficiency in man has been reported only once in association with vitamin $\mathrm{K}$ deficiency (6). The symptoms included impaired growth of hair and nails, weight loss, and a reduced response of blood clotting proteins to vitamin $\mathrm{K}$.

The manganese content of milk is about $0.02 \mathrm{ppm}(9,16)(350$ nmole/liter) and the daily intake of manganese by infants is about 180 nmole. When cereal products are added to milk the manganese intake may be much higher (15).

Casey and Robinson (4) found that the manganese content of human foetal tissue might be up to $9 \mathrm{ppm}(160 \mu \mathrm{mole} / \mathrm{kg})$ dry weight in the liver, but was much lower in other tissues. This is contrary to the earlier findings of Widdowson et al. (18) and Seeling et al. (12) that whereas copper and zinc are accumulated in foetal liver, manganese is not. The nutritional requirement for manganese in the neonate and infant is uncertain, but it has been suggested that manganese is lost in the bile regardless of the intake (3). Alexander et al. (1) have recommended an intake of about 1.0 $\mu \mathrm{mole} / \mathrm{kg} /$ day in children although, as indicated above, the intake required by neonates may be rather less. In rats the ability to maintain homeostasis develops only 17-18 days after birth (10), and manganese injected intraperitoneally is retained mainly in the liver.

Table 2. Analytical recovery of manganese (values expressed as mean \pm S.D.)

\begin{tabular}{lcc}
\hline Amount of Mn added & Amount of Mn found & Recovery \\
\hline by electrothermal atomisation & & \\
$0^{1}$ & $12.3 \pm 0.8^{1}$ & \\
25 & $13.6 \pm 2.3$ & $97 \%$ \\
50 & $59.3 \pm 3.9$ & $94 \%$ \\
by solvent extraction & & \\
$0^{2}$ & $1.4 \pm 0.2^{2}$ & \\
4 & $5.0 \pm 0.4$ & $93 \%$ \\
8 & $9.2 \pm 0.6$ & $98 \%$ \\
\hline${ }^{1}$ nmole $\cdot$ liter $^{-1}$. & & \\
${ }^{2} \mu$ mole $\cdot$ liter $^{-1}$. & &
\end{tabular}

Table 3. Precision of manganese assay

\begin{tabular}{cccc}
\hline & $\begin{array}{c}\text { Concentra- } \\
\text { tion }\end{array}$ & $\begin{array}{c}\text { No. of deter- } \\
\text { minations }\end{array}$ & $\begin{array}{c}\text { Coefficient of } \\
\text { variation } \pm \text { S.D. }\end{array}$ \\
\hline $\begin{array}{c}\text { Within batch preci- } \\
\text { sion' }\end{array}$ & & & \\
Electrothermal & $30^{2}$ & 29 & $9.4 \pm 3.9 \%$ \\
atomisation & $500^{2}$ & 29 & $9.7 \pm 4.6 \%$ \\
Solvent extraction & $1^{3}$ & 25 & $9.1 \pm 5.3 \%$ \\
& $10^{3}$ & 25 & $5.5 \pm 3.2 \%$ \\
& Concentra- $^{\text {tion }^{5}}$ & $\begin{array}{c}\text { No. of deter- } \\
\text { minations }\end{array}$ & $\begin{array}{c}\text { Coefficient of } \\
\text { variation }\end{array}$ \\
\hline
\end{tabular}

Between batch preci$\operatorname{sion}^{4}$

\begin{tabular}{cccr} 
Electrothermal & $33.3 \pm 3.2$ & 17 & $9.6 \%$ \\
atomisation & $536 \pm 62$ & 17 & $11.6 \%$ \\
\hline
\end{tabular}

${ }^{1}$ Mean coefficient of variation over several determinations.

${ }^{2}$ nmole $\cdot$ liter $^{-1}$

${ }^{3} \mu$ mole $\cdot$ liter $^{-1}$.

${ }^{4}$ Repeated assay of samples over several determinations

${ }^{5}$ Mean \pm S.D.; nmole $\cdot$ liter $^{-1}$.
Table 4. Manganese content of milk and infused fluids

\begin{tabular}{lcc}
\hline & nmole $\cdot$ liter $^{-14}$ & Range \\
\hline Milks & & \\
$\quad$ S26' & $270 \pm 140(n=8)$ & $105-1150$ \\
SMA $^{2}$ & $215 \pm 140(n=5)$ & $70-420$ \\
EBM $^{3}$ & $110 \quad(n=1)$ & \\
Dextrose 5\% & $26 \pm 28(n=17)$ & $<5-200$ \\
Saline & $40 \pm 51 \quad(n=6)$ & $5-145$ \\
Whole blood & $710 \pm 320(n=8)$ & $265-1110$ \\
Fresh frozen plasma & $215 \pm 35(n=3)$ & $195-270$ \\
Purified plasma protein & $1130 \pm 770(n=18)$ & $295-2920$ \\
\hline
\end{tabular}

' Manufacturer, John Wyeth Ltd.

${ }^{2}$ Manufacturer, Cow and Gate Ltd.

${ }^{3}$ Expressed breast milk

${ }^{4}$ Mean \pm S.D.

Table 5. Total intake and output of manganese over the balance period of 16 patients after cardiac operation

\begin{tabular}{|c|c|c|c|c|c|}
\hline \multirow[b]{2}{*}{$\begin{array}{c}\text { Patient } \\
\text { No. }\end{array}$} & \multirow[b]{2}{*}{$\begin{array}{c}\text { Intake } \\
\text { nmole } / \mathrm{kg}\end{array}$} & \multicolumn{3}{|c|}{ Output } & \multirow[b]{2}{*}{$\begin{array}{c}\text { Balance } \\
\text { nmole } / \mathrm{kg}\end{array}$} \\
\hline & & $\begin{array}{c}\text { Urine } \\
\text { nmole/kg }\end{array}$ & $\begin{array}{c}\text { Stool } \\
\text { nmole } / \mathrm{kg}\end{array}$ & $\begin{array}{c}\text { Other }^{1} \\
\text { nmole } / \mathrm{kg}\end{array}$ & \\
\hline 1 & 179 & 44.0 & 473 & 0 & -338 \\
\hline 2 & 147 & 49.0 & 644 & 0 & -497 \\
\hline 3 & 214 & 53.2 & 428 & 0 & -267 \\
\hline 4 & 989 & 38.4 & 1165 & 0 & -214 \\
\hline 5 & 222 & 36.3 & 178 & 0 & 8 \\
\hline 6 & 233 & 69.1 & 1045 & 0 & -880 \\
\hline 7 & 227 & 28.5 & 465 & 0 & -267 \\
\hline 8 & 221 & 60.5 & 986 & 38.5 & -874 \\
\hline 9 & 1000 & 31.1 & 551 & 0 & 418 \\
\hline 10 & 208 & 41.0 & 1015 & 0 & -848 \\
\hline 11 & 4413 & 83.8 & 3712 & 163 & 454 \\
\hline 12 & 318 & 145 & 1266 & 57 & -1150 \\
\hline 13 & 3095 & 118 & 1253 & 5 & 1719 \\
\hline 14 & 340 & 24.5 & 568 & 0 & -253 \\
\hline 15 & 264 & 14.7 & 360 & 0 & -111 \\
\hline 16 & 300 & 35.9 & 1094 & 0 & -830 \\
\hline
\end{tabular}

'Vomit, aspirate etc.

We have performed manganese balance studies on a group of infants recovering from surgery to correct congenital defects of the heart to assess the potential manganese requirement in the very young.

\section{MATERIALS AND METHODS}

All sixteen patients who were studied had been admitted to the Hospital for Sick Children for surgical correction of congenital defects of the heart or great vessels (Table 1). They were all boys aged from 2-248 days. Patients were studied with the informed consent of their parents or next of kin.

Balance collections were begun within $6 \mathrm{~h}$ after operation by the method described by Stevens et al. (14), and continued for up to 11 days. The manganese content of the containers used to store the samples before analysis was negligible (less than $0.2 \mu \mathrm{g}$ ). All samples were deep frozen until analysis.

Urine samples were analyzed directly by atomic absorption spectroscopy using an electrothermal graphite tube atomiser. Manganese content of other samples was determined by extracting ashed samples with 8-hydroxyquinoline in 4-methylpentan-2-one followed by flame absorption spectroscopy (5).

\section{RESULTS}

The recovery of manganese added to a normal urine sample as determined by electrothermal atomisation, and added to a pooled plasma sample as determined by solvent extraction and flame atomisation is shown in Table 2 . The within batch precision of 
the assays, as the mean within batch precision over several analytical runs is shown in Table 3. Between batch precision data for the electrothermal atomisation technique are also shown in Table 3.

The manganese contents of the milks and other fluids administered to the patients are shown in Table 4. The drugs used were also analysed and found to contribute a negligible proportion of the daily intakes (less than $0.5 \%$ ). The manganese content of the milks was low whereas the manganese content of both the whole blood and purified plasma protein (used in transfusions) was high. Fresh frozen plasma had a relatively low manganese content, similar to that of the milks. The high manganese content of the blood is due to the manganese content of the erythrocytes, whereas that of the purified plasma protein may have been acquired during processing.

The balances on the sixteen patients are summarised in Table 5. The high intakes of patients 9,11 , and 13 were due to being fed solid foods with a high manganese content during the latter stages

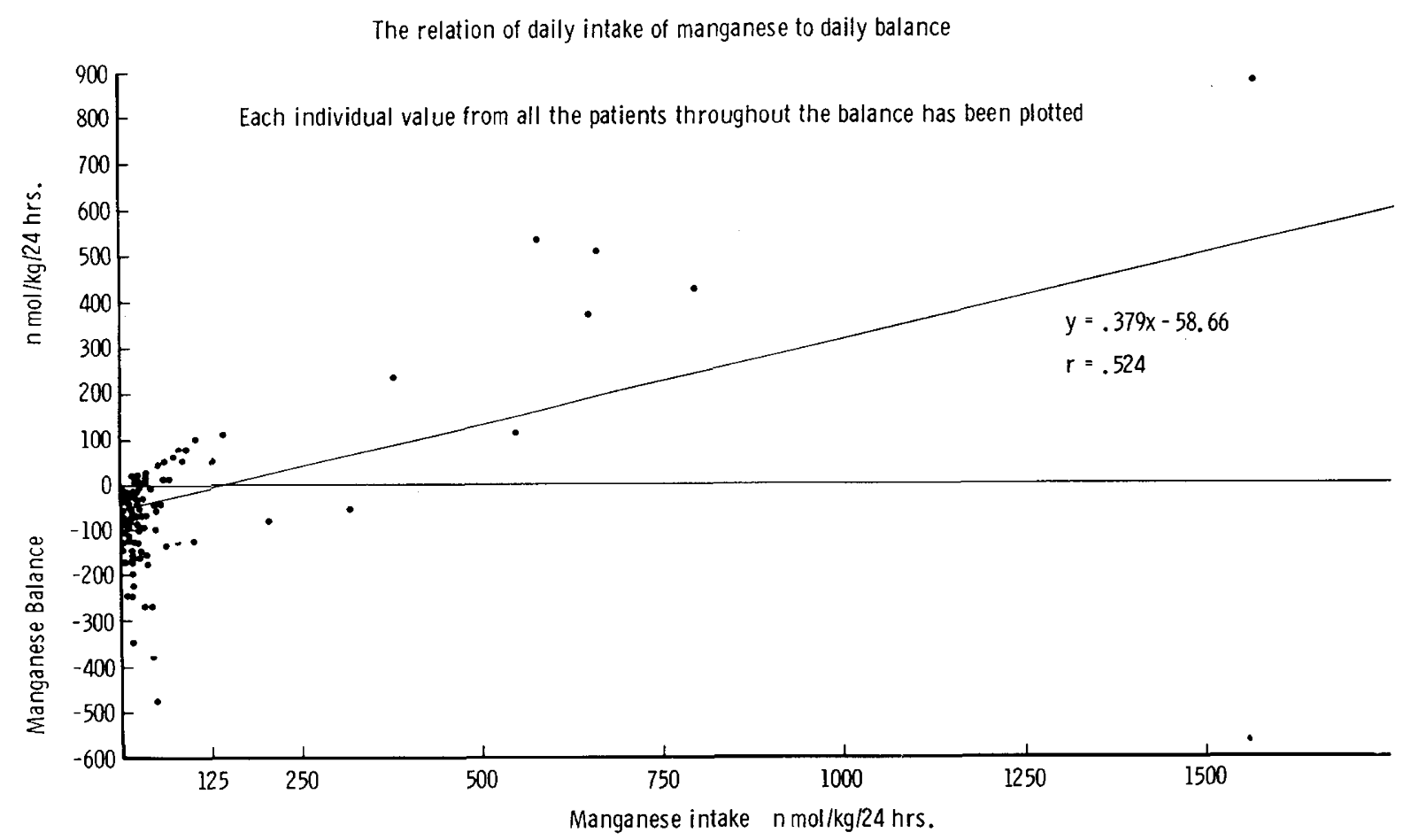

Fig. 1

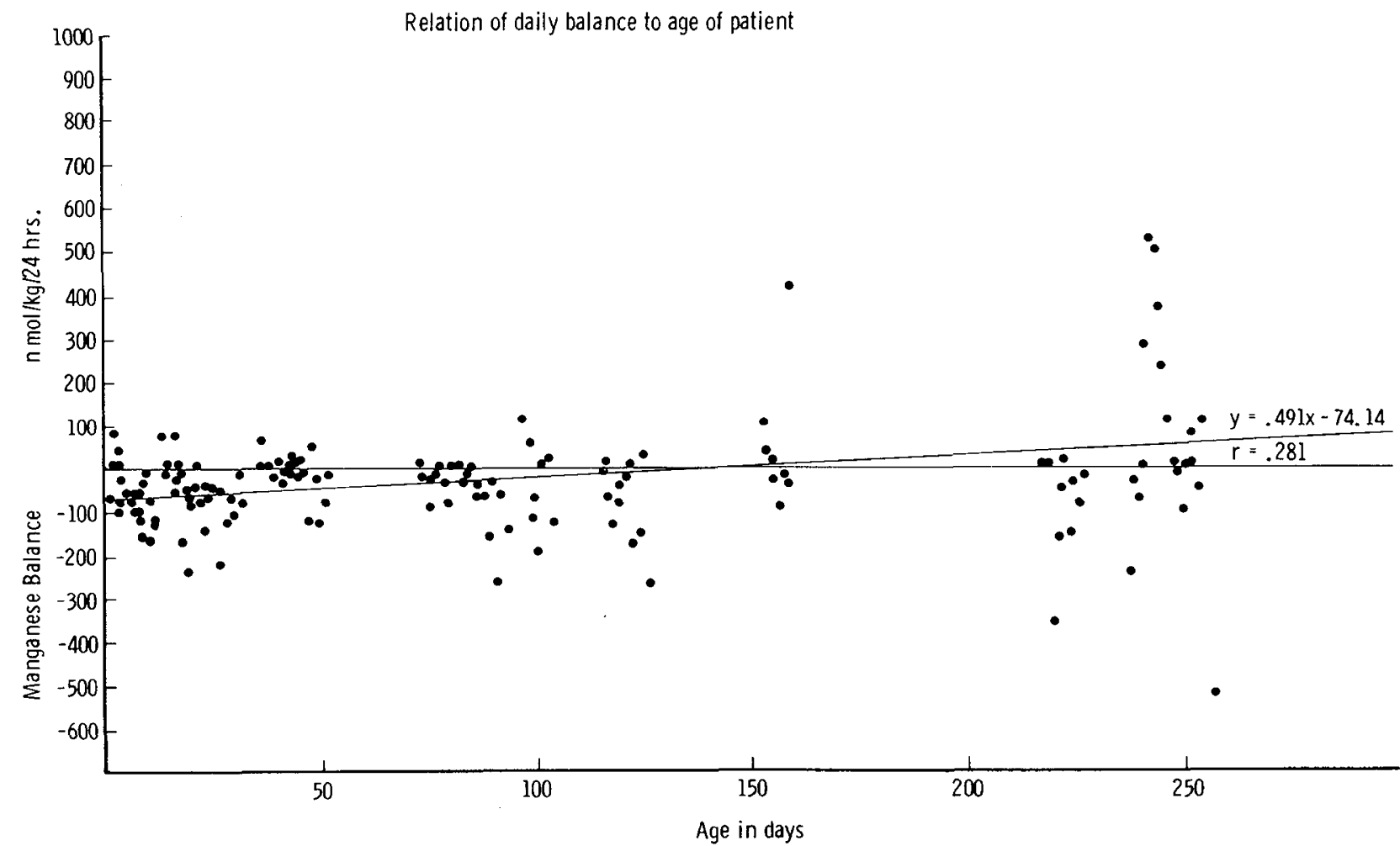

Fig. 2 
of the balance period (up to $18 \mu$ mole/day). Patient 12 received blood and plasma infusions throughout the balance period. The blood and plasma infusions during the first few days of the balance gave a much higher manganese intake in the earlier period of the study when compared with the intake of children being fed orally. The final milk intake reached $300-600 \mathrm{ml}$ per day, giving a manganese intake of 30-300 nmole per day.

There was a significant correlation between net intake and net balance $(P<0.01)$ and between the actual daily intake and daily balance $(P<0.001)$ (Fig. 1). There was no correlation between intake and urinary loss of manganese but there was a high correlation between intake and faecal loss $(P<0.001)$. There was also a correlation between the age of the patient and the intake of manganese, presumably due to the high manganese content of the food eaten by the older children. This gives an age-related correlation for the manganese balance (Fig. 2).

\section{DISCUSSION}

The urinary manganese loss was small compared to that in the faeces $(<10 \%)$. A significant correlation was found to exist between urinary chromium excretion and chromium intake (Sampson, Barlow and Wilkinson, unpublished work) in the same group of patients as studied here. The absence of such a correlation for manganese may be an indirect confirmation of the low importance of the kidneys as an excretory route for this trace element. The negative balances observed in these patients may be indictive of a degree of manganese deficiency and support the observations of Hughes and Cotzias (7) of possible manganese deficiency in neonatal mice. Widdowson records negative manganese balances in neonates of approximately $160 \mathrm{nmole} / \mathrm{kg} / \mathrm{day}(19)$.

Most manganese is excreted in the bile $(8,11)$, but biliary obstruction does not cause increased urinary loss of manganese. There is, however, increased faecal loss through intestinal secretion (2). There is an apparently important enterohepatic circulation and a mixed degree of hepatic damage (raised bilirubin and/or elevated transaminases) was observed in some patients and may account for some manganese retention. This could not be quantified. Raised plasma manganese levels are seen following myocardial infarction (13) and during acute hepatitis or cirrhosis (17).

The large negative manganese balances observed in some of the older patients (Nos. 6, 8, and 16) may be indicative of a need for supplementation with manganese. The infant may be incapable of resorbing manganese excreted in the bile and it is unlikely that positive balance can be achieved without supplementation until reaching an age of 4-5 months.

\section{REFERENCES AND NOTES}

1. Alexander, F. W., Clayton, B. E., and Delves, H. T.: Mineral and trace metal balances in children receiving normal and synthetic diets. Quart. J. Med., 43: 89 (1974).

2. Bertinchamps, A. J., Miller, S. T., and Cortzias, G. C.: Interdependence of Excreting Manganese. Am. J. Physiol., 211: 217 (1966).

3. Burch, R. E., Hahn, H. K., and Sullivan, J. F.: Newer aspects of the roles of zinc, manganese and copper in human tissues. Clin. Chem., 21: 501 (1975).

4. Casey, C. E. and Robinson, M. F.: Copper, manganese, zinc, nickel, cadium and lead in human foetal tissue. Br. J. Nutr., 39: 639 (1978).

5. Delves, H. T., Shepherd, G., and Vinter, P.: Determination of eleven metals in small samples of blood by sequential solvent extraction and atomic absorption spectroscopy. Analyst, 96: 260 (1971).

6. Doisy, E. A.: Effects of deficiency in manganese upon plasma levels of clotting proteins and cholesterol in man in Trace Element Metabolism in Animals (Ed. W. G. Hockstra et al) Proc. 2nd International Symposium; University Park Press, Baltimore pp 668.

7. Hughes, E. R. and Cotzias, G. C.: Growth, hormones and manganese. Am. J. Dis. Child., 102: 570 (1961).

8. Klassen, C. D.: Biliary excretion of metals: Drug Metab. Rev., 5: 165 (1976).

9. Mcleod, B. E. and Robinson, M. F.: Dietary intake of manganese by New Zealand infants during the first six months of life. Br. J. Nutr., 27:229 (1972)

10. Miller, S. T., Cotzias, G. C., and Evert, H. A.: Control of tissue manganese, initial absence and sudden emergence of excretion in the neonatal mouse. Am. J. Physiol., 229: 1080 (1975).

11. Papavasillou, P. S., Miller, S. T., and Cotzias, G. C.: Role of liver in regulating distribution and excretion of manganese. Am. J. Physiol., 211: 211 (1966).

12. Seeling, W., Ahnefeld, F. W., Dick, W., Maroske, G., Mayer, R., Milewski, P., and Rommel, K.: The trace elements chromium, manganese, copper and zinc in fetal liver tissue. J. Perinat., 5: 178 (1977).

13. Sparkman, T. C. and Moreland, F. B.: Serum manganese in myocardial infarction. Proc. Soc. Exp. Biol. Med., 116: 778 (1964).

14. Stevens, L. H., Hughes, E. A., and Wilkinson, A. W.: A technique of metabolic balance study in the newborn baby. Arch. Dis. Child., 37: 485 (1962).

15. Underwood, E. J.: Trace elements in human and animal nutrition. p. 170. (Academic Press New York, New York 1977).

16. Vaughan, L. A., Weber, C. W., and Kemberling, S. R.: Longitudinal changes in the mineral content of human milk. Am. J. Clin. Nutr., 32: 2301 (1979).

17. Versieck, J., Barbier, F., Speecke, A., and Harte, J.: Manganese, copper and zinc concentration in serum and packed blood cells during acute hepatitis, chronic hepatitis and post hepatitic cirrhosis. Clin. Chem., 21: 1141 (1974).

18. Widdowson, E. M., Chan, H., Harrison, G..E., and Milner, R. D. G.: Accumulation of copper, zinc, manganese, chromium and cobalt in human liver before birth. Biol. Neonat. 20: 360 (1972)

19. Widdowson, E. M.: In: Mineral metabolism in paediatrics. Ed. Barltrop, D. and Burland, W. G.; p 85. (Blackwell, Oxford and London 1969).

20. We are indebted to Dr. Jarda Stark and Dr Marc de la Rue and the nursing staff of the Cardiothoracic Unit of the Hospital for Sick Children, Great Ormond Street for their cooperation and devotion to the clinical aspects of the metabolic studies.

21. This work was made possible by a generous grant from the Stanley Thomas Johnson Trust to which we are gratefully indebted.

22. Present address and address for reprints: Department of Chemical Pathology, Charing Cross Hospital, Fulham Palace Road, London, W6 8RF.

23. Received for publication November $4,1981$.

24. Accepted for publication June 21, 1982. 